\title{
Species Composition of Odonate Fauna in Meegahawatta, a Wetland Area in Hanwella, Sri Lanka
}

\author{
M.D.H. Lankika* ${ }^{1}$, M.M.S.C. Karunaratne ${ }^{1}$ and K. Conniff ${ }^{2}$ \\ ${ }^{I}$ Department of Zoology, University of Sri Jayewardenepura, Nugegoda, Sri Lanka \\ ${ }^{2}$ K. Conniff, c/o ICIMOD, Kathmandu, Nepal
}

Date Received: 12-01-2012 Date Accepted: 21-06-2012

\begin{abstract}
Approximately 120 species of Odonata (Zygoptera and Anisoptera) have been recorded in Sri Lanka to date. There are many gaps in our knowledge of Odonata taxonomy and distribution. The present study, therefore, was carried out to investigate adult Odonata species present in Meegahawatta area $\left(1000 \mathrm{~m}^{2}\right)$ in Hanwella. The study was carried out using two fixed quadrats $(20 \mathrm{~m} \times 10 \mathrm{~m})$ randomly established in two selected sites. Total number of individuals belonging to each species was counted fortnightly by using binoculars. A total of 27 species, 11 Zygoptera and 16 Anisoptera representing eight families were recorded. This comprised of three endemic Zygopteran species (Libellago adami, Pseudagrion rubiceps ceylonicum and Prodasineura sita) and three endemic anisopteran species (Epopthalmia vittata cyanocephala, Cyclogomphus gynostylus and Macrogomphus lankanensis). Among those identified was one recently discovered and yet un-described Archibasis species. Of the three endemic Anisopteran species recorded, C. gynostylus and M. lankanensis are listed as vulnerable species in the IUCN Redlist of 2010. Although the Zygopterans showed higher Diversity Index and Evenness Index $\left(H^{\prime}=1.99, E=0.83\right)$ than the Anisopterans $\left(H^{\prime}=1.96, E=0.32\right)$, their Richness Index $(R=1.67)$ was less than that of the Anisopterans $(\mathrm{R}=2.49)$. The most common Zygopteran species recorded was Pseudagrion malabaricum whereas Neurothemis tulia tulia was the most common anisopteran species.
\end{abstract}

Key words: Odonate fauna, Anisoptera, Zygoptera, Species composition, Meegahawatta wetland area

\section{Introduction}

The order Odonata (dragonflies and damselflies) contains about 6000 described species of medium to very large insects. The highest species number is known from the Oriental region which has more than 1,000 species (Nesemann et al., 2011). It is an insect order of much interest to naturalists as well as to scientists focusing on studies in ecology or biodiversity. Although generally considered to have little economic significance, adults and larvae of all Odonate species are key predators among insects recorded frequently in aquatic ecosystems (Corbet, 1999).

Although Odonates can occupy nearly almost all kinds of habitats, aquatic habitats with high heterogeneity of vegetation are believed to be ideal for them (Wahizatul-Afzan et al., 2006), thus wetlands indicating high diversity of Odonate species. In several countries, these insects are being used as an important ecological tool to assess the quality of aquatic ecosystems such as streams, rivers, and lakes because of their high sensitivity to human disturbances (Fulan et al., 2010).

*Correspondence: harshi87@hotmail.com

Tel: $+94-723234407$

ISSN 2235-9370 Print / ISSN 2235-9362 Online C2012 University of Sri Jayewardenepura 
Even though the Odonate fauna all over the world is well-known (Arulprakash and Gunathilagaraj, 2010), there are many gaps in the knowledge of Sri Lankan odonate fauna (Bedjanic, 2004). Currently, 120 Odonate species have been identified in Sri Lanka of which 55 are Zygopterans belonging to 8 families and 65 are Anisopterans belonging to 4 families (Bedjanic, 2006; IUCN, 2007). This contains 57 endemic, 13 critically endangered, 5 endangered and 2 vulnerable species (IUCN, 2010) making the Odonate fauna in Sri Lanka a very threatened insect group (Bedjanic, 2004). The present study, therefore, was carried out in order to identify the Odonata species present in Meegahawatta wetland area as it is a locality which provides suitable habitats for a large number of fauna including Odonates. The knowledge gained thus would support the Sri Lankan Odonata checklist and is also vital for the conservation of these insects. Moreover, information on distribution and species composition is essential for further studies of biogeography and habitat usage of these insects.

\section{Materials and Methods}

\subsection{Study Area}

The present study was conducted in a forested wetland area in Hanwella known as Meegahawatta wetland $\left(1000 \mathrm{~m}^{2}\right)$. It is situated within the low country wet zone and has a tropical monsoon climate. Two sites were selected as the study area (Figure1) and the first site $(20 \mathrm{~m} \mathrm{X} \mathrm{10m)} \mathrm{comprised} \mathrm{of} \mathrm{two} \mathrm{shallow}$ water filled bogs $(2 \mathrm{~m} \mathrm{X} 0.5 \mathrm{~m})$ along the entrance of the wetland area.

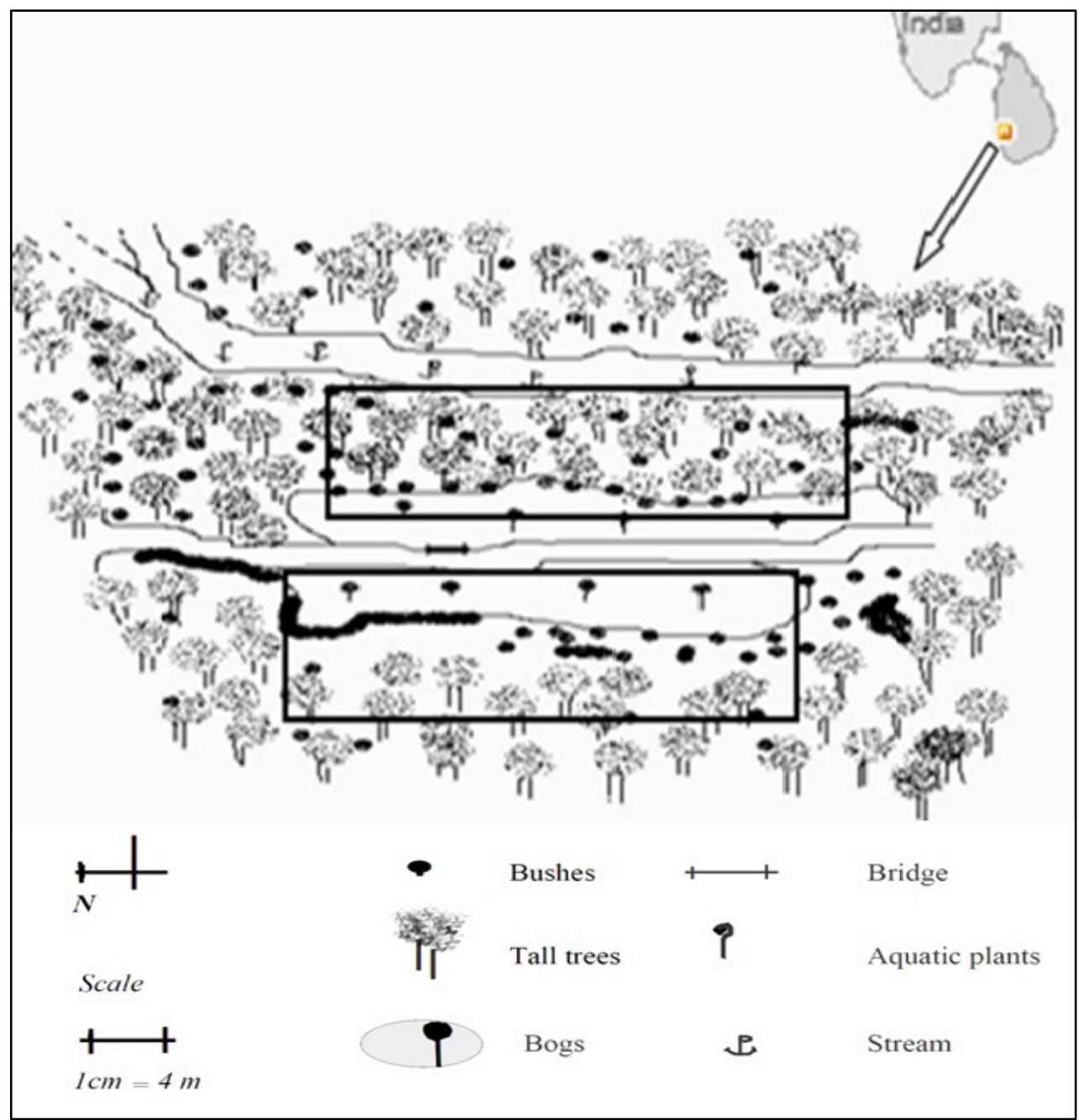

Figure 1: Study area in Meegahawatta wetland, Hanwella. The box above represents sampling site 1and the box below represents sampling site 2 
The adjacent land area with lush vegetation, mainly consisting of grasses and climbers such as Cyperus pilosus, Ischaemum timorense, Ipomoea pes-caprae and Ipomoea mauritiana is seasonally flooded. The two bogs consist of such aquatic plants as Cyperus sp., Nymphoides parriflora and Utricularia aurea. The water surface is partially covered by shrubs and trees such as Syzygium caryophyllatum and Cerbera odollam, and hence is not completely exposed to sunlight. There is a permanent small stream with clear running water at the second site $(20 \mathrm{~m} \mathrm{X} 10 \mathrm{~m})$ of the study area and a dense vegetation cover with similar grasses, climbers and trees found at the first site. The canopy is made of different types of bamboo species which somewhat covered the water surface. Except for Utricularia aurea no other aquatic plants are found in the water way.

\subsection{Sampling Method}

This study was carried out from January to May 2011. The total number of Odonata species observed inside the sampling area was recorded throughout this period. The two entire sampling sites were thoroughly scanned once in two weeks with the use of a pair of binoculars. Both sampling sites were visited on the same day and data were collected between $9.00-11.00 \mathrm{am}$. All the individuals observed and recorded were identified to the species level with reference to taxonomic keys (De Fonseka, 2000; De Silva Wijeratne et al., 2003).

\subsection{Data Analysis}

The species diversity $\left(H^{\prime}\right)$ for the study area was calculated using the Shannon Wiener Diversity Index.

$$
H^{\prime}=-\sum p_{i} \ln p_{i}
$$

Where, $p_{i}=n_{i} / N$,

$n_{i}=$ Total number of individuals belonging to $\mathrm{i}^{\text {th }}$ species,

$N=$ Total number of individuals belonging to the sampled population

Species richness index was calculated using Margalef's Richness index $(R)$.

$$
R=S-1 / \ln (\mathrm{N})
$$

Where, $S=$ Total number of species

Species evenness was calculated using Evenness index $(E)$.

$$
E=H^{\prime} / \ln (\mathrm{S})
$$

\section{Results and Discussion}

A total of 27 odonate species were identified from Meegahawatta wetland area during the study period. The odonate species recorded comprised of 11 Zygoptera species belonging to 4 families (Chlorocyphidae, Coenagrionidae, Platycnemididae and Protoneuridae) and 16 Anisoptera species belonging to 4 families (Gomphidae, Aeshnidae, Libellulidae and Corduliidae (Table 1).

The most common species recorded during the study period (Figure 2) were the Zygopteran Pseudagrion malabaricum (13\%) and the anisopteran Neurothemis tulia tulia (20\%). On the other hand, the least common species found were Ischnura aurora, Cyclogomphus gynostylus, Macrogomphus lankanensis, Orthetrum luzonicum, Rhodothermis rufa, Epopthalmia vittata cyanocephala.

According to the calculated biological indices (Figure 3), species diversity and evenness in zygopterans $(1.99,0.83)$ were higher than those of the Anisopterans $(1.96,0.32)$. However, richness index was higher in Anisopterans (2.49) than in Zygopterans (1.67). 
Table1: Odonate species composition at Meegahawatta wetland area in Hanwella, Sri Lanka during the period of January to May 2011

\begin{tabular}{|c|c|c|c|}
\hline Suborder & Family & Scientific Name & Common Name \\
\hline \multirow[t]{12}{*}{ Zygoptera } & Chlorocyphidae & Libellago adami $^{\mathrm{E}}$ (Fraser, 1939) & Adam's Gem \\
\hline & Coenagrionidae & $\begin{array}{l}\text { Agriocnemis pygmaea pygmaea } \\
\text { (Rambur, 1842) }\end{array}$ & Wandering Wisp \\
\hline & & $\begin{array}{l}\text { Ceriagrion cerinorubellum } \\
\text { (Brauer, 1866) }\end{array}$ & Painted Waxtail \\
\hline & & Ceriagrion coromandelianum (Fabricius, 1798) & Yellow Waxtail \\
\hline & & Pseudagrion malabaricum & Malabar Sprite \\
\hline & & $\begin{array}{l}\text { Pseudagrion rubriceps ceylonicum } \\
\text { 1891) }\end{array}$ & Sri Lanka Orange- faced sprite \\
\hline & & $\begin{array}{l}\text { Ischnura aurora aurora } \\
\text { (Brauer, 1865) }\end{array}$ & Dawn Bluetail \\
\hline & & Onychargia atrocyana (Selys, 1865) & Marsh Dancer \\
\hline & Platycnemididae & Copera marginipes (Rambur, 1842) & Yellow Featherlegs \\
\hline & Protoneuridae & Prodasineura sita $^{\mathbf{E}}$ (Kirby, 1893) & Stripe-headed \\
\hline & & & Treadtail \\
\hline & & Archibasis sp (nov) & - \\
\hline \multirow[t]{16}{*}{ Anisoptera } & Gomphidae & Cyclogomphus gynostylus $^{\mathbf{V , E}}$ (Fraser, 1925) & Transvestite Clubtail \\
\hline & & Macrogomphus lankanensis ${ }^{\mathbf{V}, \mathbf{E}}$ (Fraser, 1933) & Sri Lanka forktail \\
\hline & & Ictinogomphus rapax (Rambur, 1842) & Rapacious Flangetail \\
\hline & Aeshnidae & Gynacantha dravida (Fraser, 1936) & Indian Duskhawker \\
\hline & Libellulidae & Brachydiplax sobrina (Rambur, 1842) & Sombre Liutenant \\
\hline & & Orthetrum luzonicum (Brauer, 1868) & Marsh Skimmer \\
\hline & & Orthetrum sabina Sabina (Drury, 1770) & Green Skimmer \\
\hline & & $\begin{array}{l}\text { Acisoma panorpoides panorpoides (Rambur, } \\
\text { 1842) }\end{array}$ & Asian Pintail \\
\hline & & Brachythemis contaminata (Fabricius, 1793) & Asian Grounling \\
\hline & & Neurothemis tulia tulia (Drury, 1773) & Pied Parasol \\
\hline & & Rhodothemis rufa (Rambur, 1842) & Spine-legged Redbolt \\
\hline & & Trithemis aurora (Burmeister, 1839) & Crimson Dropwing \\
\hline & & Rhyothemis trianglularis (Kirby, 1889) & Blue-based Flutterer \\
\hline & & $\begin{array}{l}\text { Rhyothemis variegata variegata (Linnaeus, } \\
1763 \text { ) }\end{array}$ & Variable Flutterer \\
\hline & & Tholymis tillarga (Fabricius, 1798) & Foggy-winged Twister \\
\hline & Corduliidae & $\begin{array}{l}\text { Epophthalmia vittata cyanocephala } \\
\text { 1866) }\end{array}$ & Blue-eyed Cruiser \\
\hline
\end{tabular}

$V=$ Vulnerable, $E=$ Endemic, nov $=$ Novel

The 27 Odonate species recorded in Meegahawatta wetland area during the study period comprised of $22.5 \%$ of the total Sri Lankan Odonate fauna. This included six endemic species (Table 1) comprising three zygopteran species (Libellago adami, Pseudagrion rubiceps ceylonicum and Prodasineura sita) and three anisopteran species (Epopthalmia vittata cyanocephala, Cyclogomphus gynostylus and Macrogomphus lankanensis). Of the three endemic Anisopteran species recorded, $C$. gynostylus and M. lankanensis are listed as vulnerable species in the IUCN Redlist of 2010. Also, both of these species have been stated as a taxonomically isolated group by Bedjanic (2004). It is of great significance that the two vulnerable species recorded in the study area are the same and the only two 
vulnerable species recorded in the checklist of Sri Lanka (IUCN, 2007). Furthermore, among the identified species during the study period was one quite recently discovered and yet un-described Archibasis species. Bedjanic in 2004 also referred to a novel Archibasis sp. but it is not described as yet. This merits a great need for further studies to describe the exact species.

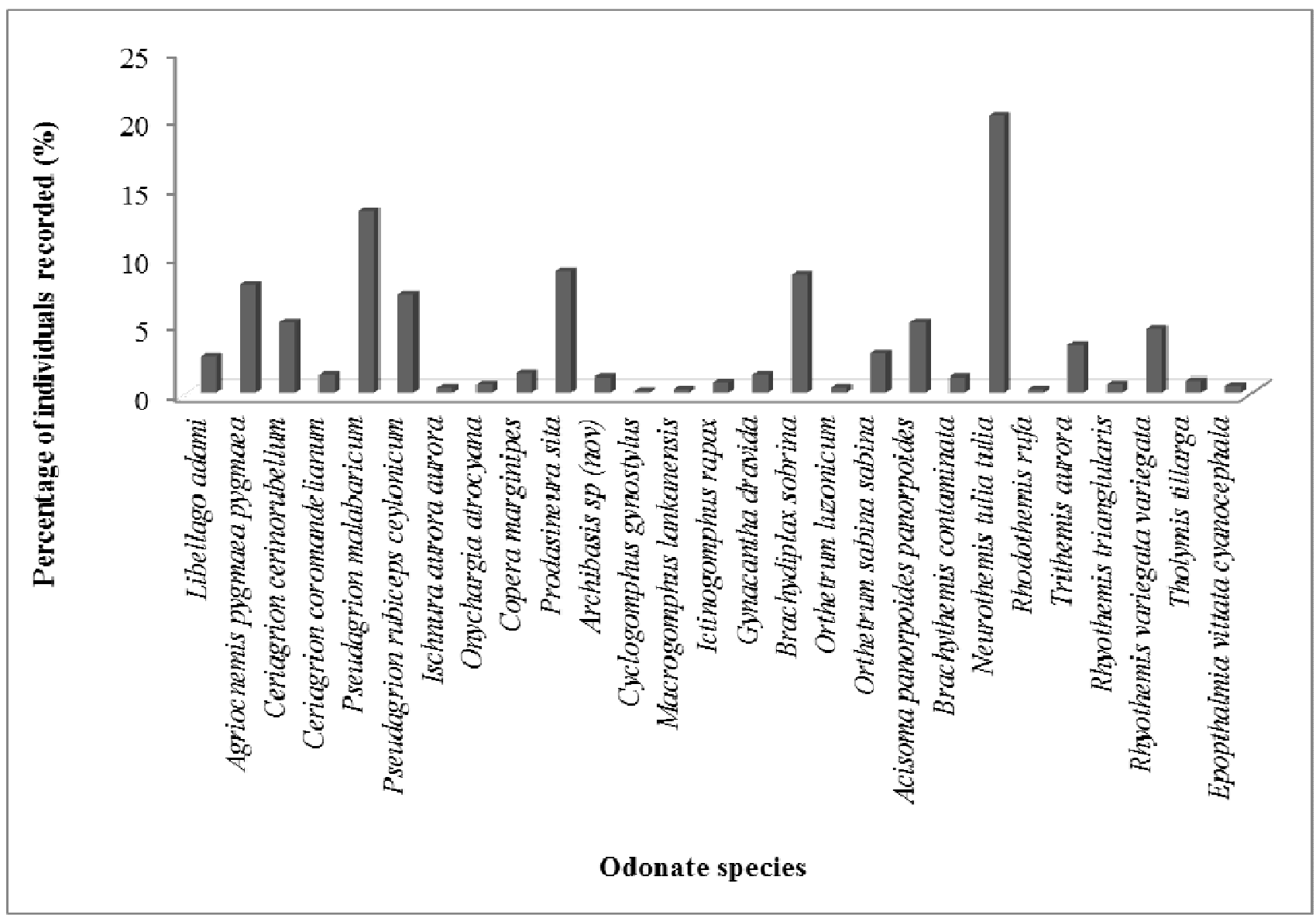

Figure 2: Odonate species composition in Meegahawatta wetland area during the study period

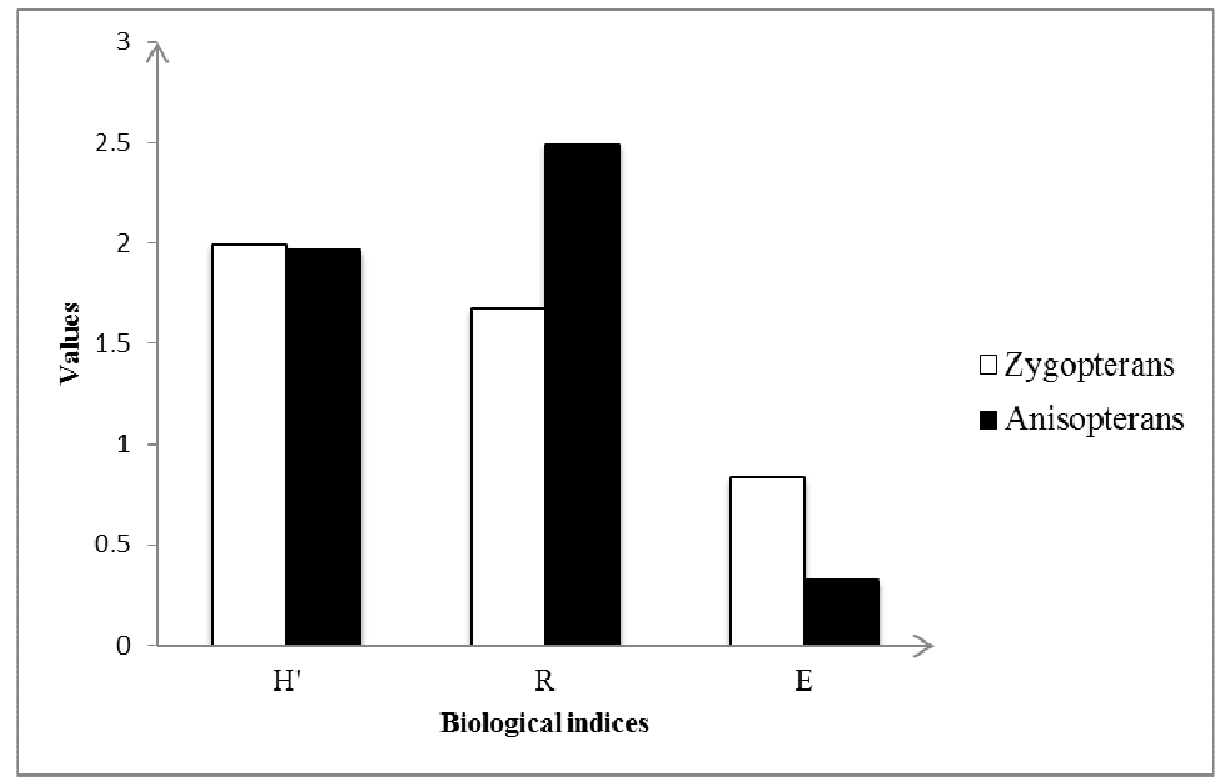

Figure 3: Species diversity, richness and evenness of Odonates recorded in Meegahawatta wetland area. H'-Shannon Wiener Diversity Index, R-Margalef Richness Index, E - Evenness Index 
Although the Odonate fauna in Sri Lanka is ecologically important, little research has been conducted so far on their distribution, abundance, biology and habitats. Hence, the data acquired in this study should, ideally be, put in an Odonatological database to generate distribution maps and also to determine their conservation status. Lastly, the presence of a relatively high number of odonate species consisting six endemic species that include two vulnerable species within this relatively small wetland area suggests urgent need to employ much needed conservation measures to safeguard this vital ecosystem.

\section{References}

Arulprakash, R and K, Gunathilagaraj. 2010. Abundance and diversity of Odonata in temporary water bodies of Coimbotore and Sahlem districts in Tamil Nadu. Journal of Threatened Taxa.2 (8):1099-1102.

Bedjanic, M. 2004. Odonata fauna of Sri Lanka: research state and threat status. International Journal of Odonatology.7 (2): 279-294.

Bedjanic, M. 2006. Current Status of Taxonomy, Research and Conservation of Dragonfly Fauna (Insect: Odonata) of Sri Lanka. The Fauna of Sri Lanka: Status of Taxonomy, Research and Conservation. Sri Lanka Government of Sri Lanka, Colombo.1:20- 30.

Corbet, P. S. 1999. Dragon flies: Behavior and Ecology. New York, USA: Cornell University Press. 829 pp.

De Fonseka.T. 2000. Dragonflies of Sri Lanka. Wild life Heritage Trust, Colombo.

De Silva Wijeratne, G., M. Bedjanic and K. Conniff, 2003. Dragonflies of Sri Lanka. Gegan's Photo Booklet.Jetwing Research Initiative,Colombo.

Fulan, J. A., R. Raimundo, D. Figueiredo and M. Correia, 2010. Abundance and diversity of dragon 7 flies four years after the construction of a reservoir. Limnetica, 29 (2): 279-286.

IUCN Sri Lanka., 2010. A comparison of the conservation and legal status of the fauna and flora of Sri Lanka. IUCN Sri Lanka, Colombo.

IUCN Sri Lanka, 2007. The 2007 Red List of Threatened Fauna and Flora of Sri Lanka. The World Conservation Union and Ministry of Environment and Natural Resources, Colombo, Sri Lanka.

Nesemann, H., R. D. T. Shah and D. N. Shah, 2011. Key to the larval stages of common Odonata of Hindu Kush Himalaya, with short notes on habitats and ecology Journal of Threatened Taxa 3(9): 2045-2060.

Wahizatul-Afzan, A. J. Julia and A. Amirrudin, 2006. Diversity and Distribution of Dragonflies (Insecta: Odonata) in Sekayu recreational forest, Terengganu. Journal of Sustainability, Science and Management. 1 (2): 97- 106. 